\title{
New Oomycota Fungicides With Activity Against Phytophthora cinnamomi and Their Potential Use for Managing Avocado Root Rot in California
}

\author{
Rodger J. Belisle, ${ }^{1}$ Wei Hao, ${ }^{1}$ Brandon McKee, ${ }^{1}$ Mary Lu Arpaia, ${ }^{2}$ Patricia Manosalva,,${ }^{1 \dagger}$ and James E. Adaskaveg, ${ }^{1, \dagger}$ \\ ${ }^{1}$ Department of Microbiology and Plant Pathology, University of California, Riverside, CA 92521 \\ ${ }^{2}$ Department of Botany and Plant Sciences, University of California, Riverside, CA 92521
}

\begin{abstract}
Phytophthora root rot (PRR), caused by Phytophthora cinnamomi, is the most destructive disease of avocado worldwide. In the United States, mefenoxam and phosphonate products are currently the only registered fungicides for managing avocado PRR. Four new Oomycota-specific and two registered fungicides, all with different modes of action, were evaluated. Seventy-one isolates of $P$. cinnamomi from avocado in California, most of them collected between 2009 to 2017, were tested for their in vitro sensitivity to the six fungicides. Baseline sensitivity ranges and mean values (in parentheses) of effective concentrations to inhibit mycelial growth by $50 \%\left(\mathrm{EC}_{50}\right)$ for the new fungicides ethaboxam, fluopicolide, mandipropamid, and oxathiapiprolin were 0.017 to $0.069 \mu \mathrm{g} / \mathrm{ml}(0.035), 0.046$ to $0.330 \mu \mathrm{g} / \mathrm{ml}(0.133), 0.003$ to $0.011 \mu \mathrm{g} / \mathrm{ml}(0.005)$, and 0.0002 to $0.0007 \mu \mathrm{g} / \mathrm{ml}(0.0004)$, respectively. In comparison, the $\mathrm{EC}_{50}$ value

soil inoculation trials with 8-month-old Zutano seedlings and 10-monthold Dusa and PS.54 clonal rootstocks were conducted to assess the efficacy of these fungicides for managing PRR. Mefenoxam and potassium phosphite were effective treatments; however, oxathiapiprolin, fluopicolide, and mandipropamid were more effective. Ethaboxam was effective in reducing PRR on the rootstocks evaluated. Oxathiapiprolin reduced PRR incidence and pathogen population size in the soil by $>90 \%$, and plant shoot growth and root dry weight were significantly increased compared with the control; thus, oxathiapiprolin was one of the best treatments overall. The high activity and performance of these new fungicides supports their registrations on avocado for use in rotation and mixture programs, including with previously registered compounds, to reduce the risk of development and spread of resistance in pathogen populations.
\end{abstract} range (mean) was 0.023 to $0.138 \mu \mathrm{g} / \mathrm{ml}(0.061)$ for mefenoxam and 12.9 to $361.2 \mu \mathrm{g} / \mathrm{ml}$ (81.5) for potassium phosphite. Greenhouse
Keywords: disease management, oomycetes
Phytophthora root rot (PRR) caused by Phytophthora cinnamomi Rands is the most important disease of avocado and limits production in California, Florida, and other locations worldwide. P. cinnamomi kills feeder roots and can also cause trunk cankers, resulting in reduced fruit yield and often tree death (Hardham 2005). PRR historically affected 60 to $75 \%$ of California avocado growers, causing losses of $\$ 40$ million annually (Coffey 1987). Major expenditures for managing PRR include cost and application of fungicides. Favorable conditions for spread and proliferation of the pathogen are wet, poorly drained soils at a wide range of temperatures (Erwin and Ribeiro 1996). The main infection propagules of $P$. cinnamomi are zoospores that are chemotactically attracted to the roots of plants (Zentmyer 1961). Chlamydospores, long-term resting structures, enable $P$. cinnamomi to persist in the soil for many years, making it nearly impossible to completely eliminate the pathogen once the soil is infested (McCarren et al. 2005).

Avocado PRR management includes the use of resistant rootstocks, proper irrigation practices, and chemical treatments (Coffey 1987). Commercially available, moderately resistant rootstocks include Dusa, Toro Canyon, Duke 7, Steddom, Uzi, and Zentmyer (Bender et al. 2013). Among them, Dusa is the current California industry standard enabling growers to cultivate avocado in $P$.

${ }^{\dagger}$ Corresponding authors: P. Manosalva; patricia.manosalva@ucr.edu, and J. E. Adaskaveg; jim.adaskaveg@ucr.edu

\section{R. J. Belisle and W. Hao contributed equally to this work.}

Funding: This work was financially supported by the University of California Riverside (Initial Complement Funds) and the California Avocado Commission (grant 008599-002).

The author(s) declare no conflict of interest.

Accepted for publication 17 March 2019.

(C) 2019 The American Phytopathological Society cinnamomi-infested soil and maintain production. However, resistance of this rootstock is challenged by a new clonal group of more virulent $P$. cinnamomi isolates identified in California (Belisle et al. 2019; Pagliaccia et al. 2013). Cultural management practices include mulching, gypsum application, and proper irrigation (Coffey 1987) using water sources not contaminated with propagules of $P$. cinnamomi (Mircetich et al. 1985). The pathogen has a very broad host range and is capable of infecting more than 5,000 plant species (Kamoun et al. 2015; Zentmyer 1980). Thus, even with the best management program, the pathogen can be reintroduced into an orchard from other plants or with irrigation and run-off water.

At present, the only fungicides available to control PRR of avocado are phosphonate-based compounds (e.g., potassium phosphite; Fungicide Resistance Action Committee [FRAC] code P07, formerly code 33) (Fungicide Resistance Action Committee 2018) and phenylamide compounds (e.g., mefenoxam; FRAC code 4). Mefenoxam is an $R$-enantiomer of metalaxyl that was introduced in 1977. It has been effectively used for managing diseases caused by Phytophthora spp. and other Oomycota organisms (Hu et al. 2010). Mefenoxam is strongly inhibitory to mycelial growth and sporulation of these organisms because it interferes with RNA polymerases and blocks RNA synthesis (Müller and Gisi 2012) to these organisms. The risk of phenylamide resistance development is considered high because of a single-site mode of action (Gisi and Sierotzki 2015), and resistance has developed in $P$. infestans, $P$. citricola, $P$. megasperma, and $P$. nicotianae only a few years after metalaxyl and mefenoxam became available for use (Coffey et al. 1984; Ferrin and Kabashima 1991; Gisi and Sierotzki 2015; Hwang and Benson 2005; Stack and Millar 1985). Little information is available on the sensitivity of $P$. cinnamomi populations to mefenoxam (Benson and Grand 2000; Duan et al. 2008; Hu et al. 2010), and no information is currently available for isolates from avocado in California where this fungicide is mostly used by the nursery industry.

Phosphorous acid and its ionized compounds (i.e., phosphites) belong to the phosphonate group of fungicides. The specific mode of action of phosphite is largely unknown, but direct inhibition of pathogen growth (Dobrowolski et al. 2008; Fenn and Coffey 1984; Ma 
and McLeod 2014; Ouimette and Coffey 1989) and induction of the host plant defense system appear to be involved (Eshraghi et al. 2014; Groves et al. 2015; King et al. 2010). Reduced in vitro sensitivity to potassium phosphite in several Phytophthora spp., including $P$. capsici, $P$. cinnamomi, $P$. citrophthora, $P$. infestans, and $P$. syringae, has been reported (Adaskaveg et al. 2017; Cohen and Samoucha 1984; Veena et al. 2010; Wilkinson et al. 2001). Potassium phosphite is the preferred PRR control treatment by avocado growers because it is less expensive than mefenoxam. Its optimal application by trunk injection, however, can be labor intensive and costly, and injection sites provide entry points for insect pests (Eskalen and Faber 2016).

New Oomycota fungicides with different modes of action from mefenoxam and phosphonate fungicides have become available. Ethaboxam, a thiazole carboxamide (FRAC code 22), disrupts microtubule organization in Oomycota (Uchida et al. 2005). Fluopicolide is a pyridinylmethyl-benzamide (FRAC code 43) that disrupts cell division and mitosis by acting on spectrin-like proteins (Briggs et al. 2006; Jiang et al. 2015). Mandipropamid is a carboxylic acid amide (CAA; FRAC code 40) fungicide targeting the pathogen cellulose synthase gene that is involved in cell wall biosynthesis (Gisi and Sierotzki 2015). Oxathiapiprolin, a piperidinyl-thiazoleisoxazoline (FRAC code 49), targets the oxysterol-binding protein (OSBP) of Oomycota organisms (Miao et al. 2016a).

The goal of this study was to determine whether the new Oomycota fungicides could be used to manage PRR of avocado. Thus, the objectives were to establish baseline sensitivities of a large number of isolates of $P$. cinnamomi representing the current pathogen population on avocado in California, compare these sensitivities to those of mefenoxam and potassium phosphite, and evaluate the efficacy of the four new fungicides compared with the two registered ones for the management of PRR of avocado seedlings and clonal rootstocks in greenhouse studies.

\section{Materials and Methods}

Isolates of $P$. cinnamomi used in this study. A total of $71 P$. cinnamomi isolates were obtained from avocado roots and rhizosphere soil from northern (Los Angeles, Santa Barbara, and Ventura counties) and southern (Riverside and San Diego counties) avocado growing regions in California (Table 1). Fifty-three isolates were identified previously, including 32 isolates from an earlier study
(Pagliaccia et al. 2013), and 18 isolates were identified in this study. Isolates were maintained as agar plugs in water during the study and long term in liquid nitrogen. The pathogen was cultured on $10 \%$ clarified V8 (V8C) agar (Ribeiro 1978).

The identity of the 18 recently recovered isolates was confirmed by sequencing the rDNA internal transcribed spacer (ITS) region (Cooke and Duncan 1997; Cooke et al. 2000). Mycelial DNA was extracted using the Qiagen DNeasy plant mini kit (Qiagen, Germantown, MD). Universal primers ITS1 and ITS4 (White et al. 1990) were used in PCR reactions. Each $25-\mu 1$ reaction contained $2 \mu \mathrm{l}$ of DNA (50 ng/ $\mu \mathrm{l}), 2.5 \mu \mathrm{l}$ of 10× PCR buffer (New England Biolabs, Ipswich, MA), $200 \mu \mathrm{M}$ of dNTPs, $0.4 \mu \mathrm{M}$ of each primer, and 1.25 units of Taq DNA polymerase (New England Biolabs). PCR reactions were performed using a programmed thermal controller (T100; Bio-Rad Laboratories, Hercules, CA) with conditions as follows: $95^{\circ} \mathrm{C}$ for $5 \mathrm{~min}$; followed by 35 cycles at $95^{\circ} \mathrm{C}$ for $1 \mathrm{~min}, 50^{\circ} \mathrm{C}$ for $1 \mathrm{~min}$, and extension at $68^{\circ} \mathrm{C}$ for $1 \mathrm{~min}$; and a final extension at $68^{\circ} \mathrm{C}$ for $10 \mathrm{~min}$. PCR products were visualized in ethidium bromidestained $1 \%$ agarose gels. PCR products were treated with Zymo DNA Clean \& Concentrator (Zymo Research Corp., Irvine, CA) to remove excess primers and nucleotides and were sequenced in both directions (Eurofins Genomics, Louisville, KY). Consensus sequences were generated using BioEdit (version 7.2.5) (Hall 1999) and submitted to BLASTn searches of the GenBank nucleotide database (https:// www.ncbi.nlm.nih.gov/).

Fungicides used. Fungicides used included ethaboxam (Intego; Valent USA, Walnut Creek, CA), fluopicolide (Presidio; Valent USA), mandipropamid (Revus; Syngenta Crop Protection, Greensboro, NC), oxathiapiprolin (Orondis OD; Syngenta Crop Protection), mefenoxam (Ridomil Gold SL; Syngenta Crop Protection), and potassium phosphite (ProPhyt; Helena Chemical, Collierville, TN) (Table 2).

In vitro fungicide sensitivities of $\boldsymbol{P}$. cinnamomi isolates. The sensitivity of mycelial growth of $P$. cinnamomi to potassium phosphite was tested using an agar dilution method. Potassium phosphite was amended to $10 \% \mathrm{~V} 8 \mathrm{C}$ agar to obtain final concentrations of 0 (control), 5, 25, 50, 100, 150, 300, or $600 \mu \mathrm{g} / \mathrm{ml}$. Each triplicated Petri dish for each concentration was inoculated in the center with a mycelial agar plug (6 $\mathrm{mm}$ in diameter) from 7- to 8-day-old cultures. After incubation in the dark at $22^{\circ} \mathrm{C}$ for 3 days, radial colony growth

Table 1. Isolates of Phytophthora cinnamomi from California used in this study

\begin{tabular}{llll}
\hline No. of isolates & \multicolumn{1}{c}{ Year collected } & County of origin & Source \\
\hline 34 & $2004,2005,2008,2009,2015,2017$ & San Diego & Avocado roots, rhizosphere \\
12 & $2009,2011,2015,2016$ & Riverside & Avocado roots, rhizosphere \\
1 & 2015 & Los Angeles & Avocado roots, rhizosphere \\
13 & $1996,2009,2010,2017$ & Ventura & Avocado roots, rhizosphere \\
10 & 2010,2017 & Santa Barbara & Avocado roots, rhizosphere \\
1 & Unknown & Unknown & Avocado roots \\
\hline
\end{tabular}

Table 2. Fungicides and application rates used in this study

\begin{tabular}{|c|c|c|c|c|c|}
\hline \multirow[b]{2}{*}{ Active ingredient } & \multirow[b]{2}{*}{ Product name } & \multirow[b]{2}{*}{ Registrant } & \multirow[b]{2}{*}{ FRAC $\operatorname{code}^{x}$} & \multicolumn{2}{|c|}{ Application rate } \\
\hline & & & & Field $(\mathrm{g} / \mathrm{ha})^{\mathrm{y}}$ & Greenhouse (g/pot) ${ }^{\mathbf{z}}$ \\
\hline Ethaboxam $34.2 \%$ & Intego & Valent USA & 22 & 702 & 0.140 \\
\hline \multirow[t]{2}{*}{ Fluopicolide $39.5 \%$} & Presidio & Valent USA & 43 & 140 & 0.028 \\
\hline & & & & 210 & 0.042 \\
\hline \multirow[t]{2}{*}{ Mandipropamid $23.3 \%$} & Revus & Syngenta Crop Protection & 40 & 146 & 0.029 \\
\hline & & & & 292 & 0.058 \\
\hline Mefenoxam $45.3 \%$ & Ridomil Gold SL & Syngenta Crop Protection & 4 & 561 & 0.112 \\
\hline \multirow{2}{*}{ Oxathiapiprolin $9.4 \%$} & Orondis OD & Syngenta Crop Protection & 49 & 70 & 0.014 \\
\hline & & & & 140 & 0.028 \\
\hline Potassium phosphite $54.5 \%$ & ProPhyt & Helena Chemical & 33 & 2,353 & 0.469 \\
\hline
\end{tabular}

${ }^{\mathrm{x}}$ Fungicide Resistance Action Committee (2018).

${ }^{y}$ Registrant-recommended field application rates for tree crops (Hao et al. 2019) were used to calculate greenhouse rates for avocado. Field rates per tree were calculated based on 346 trees/ha.

${ }^{\mathrm{z}}$ Greenhouse rates per pot were calculated from field rates per tree based on the soil area per tree/soil area per pot $=14.5: 1$. 
was measured. Mycelial growth percent inhibition of each isolate was calculated compared with the control. This experiment was done twice. Effective concentrations to inhibit $50 \%$ of mycelial growth $\left(\mathrm{EC}_{50}\right.$ values) were determined as described previously (Adaskaveg et al. 2015).

The sensitivity of mycelial growth to ethaboxam, fluopicolide, mandipropamid, mefenoxam, and oxathiapiprolin was evaluated using the spiral gradient dilution (SGD) method (Förster et al. 2004; Gray et al. 2018). Isolates were grown on sterile hydrophilic cellophane strips $(5.5 \mathrm{~cm} \times 0.5 \mathrm{~cm}$; du Pont de Nemours, Wilmington, DE) that were placed onto V8C agar. Mycelium-covered agar strips of 1-week-old cultures were placed between the cellophane strips. Plates were then incubated in the dark at $22^{\circ} \mathrm{C}$ for 7 to 9 days until mycelia had grown evenly over the cellophane strips. Aqueous stock solutions of ethaboxam $(50 \mu \mathrm{g} / \mathrm{ml})$, fluopicolide $(100 \mu \mathrm{g} / \mathrm{ml})$, mandipropamid $(10 \mu \mathrm{g} / \mathrm{ml})$, mefenoxam $(50 \mu \mathrm{g} / \mathrm{ml})$, or oxathiapiprolin $(5 \mu \mathrm{g} / \mathrm{ml})$ or water (control) were plated onto $15-\mathrm{cm} \mathrm{V8C} \mathrm{agar} \mathrm{plates}$ using a spiral plater (Autoplate 4000; Spiral Biotech, Norwood, MA) set at the exponential mode. Mycelium-covered cellophane strips were radially placed across the fungicide concentration gradient on the SGD plates. For each isolate, two strips were placed on opposite sides of duplicated plates, and the experiment was repeated. SGD plates were incubated in the dark at $22^{\circ} \mathrm{C}$ for 2 days. The location where mycelial growth was inhibited by $50 \%$ was determined, and local fungicide concentrations $\left(\mathrm{EC}_{50}\right.$ values) were calculated using SGE software (Spiral Biotech).

Efficacy of Oomycota fungicides to control PRR of avocado seedlings and clonal rootstocks in greenhouse studies. Six- to 8month-old avocado (Persea americana Mill. Zutano) seedlings and 10-month-old clonal rootstocks, Dusa and PS.54 (Westfalia Technological Services, Tzaneen, South Africa), were obtained from local nurseries. Plants were transplanted into 19-liter free-draining pots using UC-A soil mix (Matkin and Chandler 1957). The average air temperature was between 25 and $28^{\circ} \mathrm{C}$, and the relative humidity was between 40 and $50 \%$ during the experiments in the greenhouse. Plants were fertilized (Peters Excel 21-5-20; Scotts Miracle-Gro, Marysville, $\mathrm{OH}$ ) once at the beginning of the studies and watered about 1 liter per pot three times a week throughout the study.

Plants were inoculated using $P$. cinnamomi-colonized millet seeds (Drenth and Sendall 2001). For this, $175 \mathrm{ml}$ of sterile distilled water was added to $144 \mathrm{~g}$ of millet seeds in a 500-ml flask, and flasks were autoclaved for $30 \mathrm{~min}$ on 2 consecutive days. Ten plugs $(6 \mathrm{~mm}$ in diameter) of a 4-day-old $P$. cinnamomi culture were added to each flask, and flasks were incubated in the dark at $25^{\circ} \mathrm{C}$ for 21 days. Equal proportions of seeds colonized by isolates 2109, 2117, or 2120 (obtained from avocado roots or rhizosphere soil in San Diego and Riverside counties) were mixed to prepare the final inoculum, and $4.4 \mathrm{~g}$ of inoculum was added to the soil around the base of the stem of each plant. Plants were then watered with approximately $500 \mathrm{ml}$ per pot.

All fungicides were applied as a soil drench 1 week after inoculation. Two rates of fluopicolide, mandipropamid, and oxathiapiprolin were applied to seedlings. Only the high rates of fluopicolide, mandipropamid, and oxathiapiprolin and one rate of ethaboxam were applied to two rootstocks; one rate of each mefenoxam and potassium phosphite was applied to seedlings and rootstocks (Table 2). Fungicide application rates used for citrus (Hao et al. 2019) were used to calculate greenhouse rates for avocado based on the ratio of soil surface area of a tree in the field to a potted plant. Seedlings and rootstocks were arranged in a randomized complete block design. Ten and six single-pot replicates were used for seedlings and rootstocks, respectively. Fungicides $(50 \mathrm{ml})$ were applied to the soil around the plant in each pot. Water $(500 \mathrm{ml})$ was added to each pot immediately after application to move the fungicide into the soil. Inoculated plants treated with water were used as controls.

The efficacy of fungicide treatments was evaluated based on PRR incidence and pathogen population sizes in rhizosphere soil 16 to 17 weeks after fungicide applications. Soil in each pot was loosened by gently shaking the pot and the root ball of each plant was removed. Soil (approximately $100 \mathrm{~g}$ ) was sampled next to roots (i.e., rhizosphere soil) from each pot. Root balls were then rinsed with tap water. Feeder roots were cut into $1-\mathrm{cm}$-long pieces using a sterilized razor blade, and 20 pieces were placed onto each of two plates of Phytophthora-selective medium PARHFB-V8C (Ferguson and Jeffers 1999; Hao et al. 2018). When present, root pieces with discoloration were selected. Plates were incubated at $22^{\circ} \mathrm{C}$ for 2 to 3 days in the dark. P. cinnamomi colonies were identified by the distinctive coralloid-type mycelium with abundant hyphal swellings (Erwin and Ribeiro 1996), and representative colonies were subcultured and verified for species identity using speciesspecific TaqMan quantitative PCR (Bilodeau et al. 2014; Miles et al. 2017). PRR incidence was calculated as the percentage of $P$. cinnamomi-infected root pieces of the total pieces plated.

For enumeration of soil populations, $10 \mathrm{~g}$ of rhizosphere soil from each plant was mixed with $90 \mathrm{ml}$ of sterile distilled water in a $250-\mathrm{ml}$ Erlenmeyer flask containing three stainless steel beads $(6 \mathrm{~mm}$ in diameter) on a rotary shaker (G24 Environmental incubator shaker; New Brunswick Scientific, Edison, NJ) at $150 \mathrm{rpm}$ for $30 \mathrm{~min}$. Aliquots of 1-ml soil suspension were spread onto two plates of PARHFB-V8C agar per plant. Plates were rinsed with water after $24 \mathrm{~h}$ at $22^{\circ} \mathrm{C}$ in the dark and incubated for another 2 to 3 days in the dark, and P. cinnamomi colonies were enumerated. Phytophthora propagule populations were calculated as CFU per gram of soil.

Dry weights of shoots of Zutano seedlings and roots of all plants were determined after drying at $50^{\circ} \mathrm{C}$ for 5 days. The experiment was conducted twice using avocado seedlings and once on each of two clonal rootstocks, Dusa and PS.54.

Statistical analysis. Mean $\mathrm{EC}_{50}$ values for each isolate and fungicide to inhibit mycelial growth were analyzed using frequency histograms. The standard deviation was calculated from $\log _{10}$-transformed $\mathrm{EC}_{50}$ values for ethaboxam, fluopicolide, mandipropamid, mefenoxam, oxathiapiprolin, and potassium phosphite. For each fungicide, the mean standard deviation of all isolates was used to calculate $\mathrm{EC}_{50}$ category bin widths as described by Scott (1979) using the following equation:

$$
\mathrm{h}_{\mathrm{n}}=3.49 \mathrm{sn}^{-1 / 3}
$$

where $\mathrm{h}$ is the bin width of each $\mathrm{EC}_{50}$ category group, $\mathrm{s}$ is the mean standard deviation of all isolates, and $\mathrm{n}$ is the number of isolates tested. The number of isolates in each bin was determined, and bins were graphed in frequency histograms over the $\mathrm{EC}_{50}$ range.

For comparisons of the toxicity of the six fungicides for all isolates and for isolates from southern and northern growing regions, $\mathrm{EC}_{50}$ values were $\log _{10}$-transformed, variances were analyzed using the Bartlett test of homogeneity, and homogenous data sets were combined. Mean $\mathrm{EC}_{50}$ values for each fungicide for all isolates and for isolates from each growing region were compared using analysis of variance (ANOVA) for balanced data sets. For comparing $\mathrm{EC}_{50}$ values of fungicides, isolates from the two growing regions, and their interaction, a two-way analysis was performed using general linear model (GLM) procedures for unbalanced data sets and the Tukey studentized range test for multiple mean comparisons with a $95 \%$ family-wise confidence level.

For repeated greenhouse experiments, the homogeneity of variances was tested using the Bartlett test of homogeneity. Homogenous data sets were combined and analyzed using ANOVA, and differences between means of treatments were determined using the Fisher least significant difference test. ANOVA, GLM, homogeneity, and mean separation analyses were performed in SAS software (version 9.4; SAS Institute, Inc., Cary, NC). Results were considered significant at $P \leq 0.05$.

\section{Results}

Identification of isolates. ITS sequences of 18 recently collected isolates were 784 to $799 \mathrm{bp}$ long. BLASTn searches showed that all had a $99 \%$ similarity to reference sequences of $P$. cinnamomi. Representative sequences were deposited in GenBank (accession numbers MH842130, MH842131, MH842132, MH842133, MH842134, MH842135, and MH842136 for isolates 346, 345, 344, 343, 341, 338 , and 337, respectively). 
In vitro fungicide sensitivities of $\boldsymbol{P}$. cinnamomi isolates. All 71 isolates evaluated were highly sensitive to ethaboxam, fluopicolide, mandipropamid, oxathiapiprolin, and mefenoxam. $\mathrm{EC}_{50}$ value ranges (means) for the six fungicides were 0.017 to $0.069 \mu \mathrm{g} / \mathrm{ml}$ (0.035), 0.046 to $0.330 \mu \mathrm{g} / \mathrm{ml} \mathrm{(0.133),} 0.003$ to $0.011 \mu \mathrm{g} / \mathrm{ml}$ (0.005), 0.0002 to $0.0007 \mu \mathrm{g} / \mathrm{ml}$ (0.0004), 0.023 to $0.138 \mu \mathrm{g} / \mathrm{ml}(0.061)$, and 12.9 to $361.2 \mu \mathrm{g} / \mathrm{ml}(81.5)$ for ethaboxam, fluopicolide, mandipropamid, oxathiapiprolin, mefenoxam, and potassium phosphite, respectively (Table 3 ). Differences in the range of sensitivities for ethaboxam, fluopicolide, mandipropamid, oxathiapiprolin, and mefenoxam were 4.1-, 7.2-, 3.7-, 3.5-, and 6.0 -fold, respectively. For potassium phosphite, a wider sensitivity range with a 28 -fold difference between the least and the most sensitive isolate was observed. The mean $\mathrm{EC}_{50}$ values for all isolates were significantly different for each fungicide and for the isolates collected within each of the two regions (Table 3). Oxathiapiprolin had the lowest mean $\mathrm{EC}_{50}$ value of $0.0004 \mu \mathrm{g} / \mathrm{ml}$ for all isolates evaluated.

There was a significant interaction $(P<0.001)$ of fungicides and geographical origin of isolates in the two-way GLM analysis. Mean $\mathrm{EC}_{50}$ values for isolates from southern and northern growing regions were not significantly different for ethaboxam $(P=0.362)$, fluopicolide $(P=0.637)$, mandipropamid $(P=0.217)$, oxathiapiprolin $(P=$ $0.053)$, and mefenoxam $(P=0.866)$. For potassium phosphite, however, mean values for isolates from southern growing regions (i.e., $98.9 \mu \mathrm{g} / \mathrm{ml})$ were significantly $(P=0.001)$ higher than those from northern regions (i.e., $47.3 \mu \mathrm{g} / \mathrm{ml}$ ) (Table 3).

Frequency histograms of $\mathrm{EC}_{50}$ values for ethaboxam, fluopicolide, mandipropamid, oxathiapiprolin, and mefenoxam exhibited a unimodal distribution of sensitivities for the isolates tested (Fig. 1). In contrast, the frequency histogram for potassium phosphite showed a bimodal distribution representing populations of isolates with different $\mathrm{EC}_{50}$ value ranges (Fig. 2). Thirty-eight isolates had values (means) in a range from 12.9 to $59.7 \mu \mathrm{g} / \mathrm{ml}$ (24.5), whereas the remaining 33 isolates exhibited a reduced sensitivity with $\mathrm{EC}_{50}$ values in a range from 79.1 to $361.2 \mu \mathrm{g} / \mathrm{ml}(147.0)$.

Isolates 2109,2117 , and 2120 that were used for inoculations in the greenhouse studies had $\mathrm{EC}_{50}$ values of $0.057,0.048$, and $0.060 \mu \mathrm{g} / \mathrm{ml}$ for ethaboxam; $0.125,0.106$, and $0.099 \mu \mathrm{g} / \mathrm{ml}$ for fluopicolide; $0.004,0.004$, and 0.003 for mandipropamid; 0.0003 , 0.0002 , and $0.0002 \mu \mathrm{g} / \mathrm{ml}$ for oxathiapiprolin; 0.055, 0.061, and $0.068 \mu \mathrm{g} / \mathrm{ml}$ for mefenoxam; and 116.7, 120.0, and $165.3 \mu \mathrm{g} / \mathrm{ml}$ for potassium phosphite, respectively.

Efficacy of Oomycota fungicides to control PRR of Zutano avocado seedlings in greenhouse studies. All fungicide treatments evaluated significantly $(P<0.05)$ reduced PRR incidence and $P$. cinnamomi propagule populations in rhizosphere soil compared with the untreated infected control (Fig. 3). Oxathiapiprolin at the high rate of $0.028 \mathrm{~g} / \mathrm{pot}$ resulted in the lowest incidence of PRR with a $95 \%$ reduction from the untreated control where $82 \%$ of the plated root pieces were found to be colonized by P. cinnamomi (Fig. 3A). The lower rate of this fungicide was also very effective and was statistically similar to either rate of fluopicolide. The low rate of fluopicolide $(0.028 \mathrm{~g} / \mathrm{pot})$ performed similar to either rate of mandipropamid, whereas mefenoxam and potassium phosphite were the least effective, with reductions in PRR incidence from the control of 51 and $43 \%$, respectively. Oxathiapiprolin at either rate most effectively reduced the number of viable $P$. cinnamomi propagules in the soil compared with all other treatments (Fig. 3B). All other treatments significantly reduced pathogen populations compared with the control, and there were no significant differences among these latter fungicides (Fig. 3B).

Variances of shoot and root dry weights were not homogenous between experiments according to the Bartlett test $(P=0.030$ and $P=$ 0.013 for shoot and root dry weight, respectively); thus, data are presented for each experiment (Table 4). Similar trends were observed for most of the treatments in the two experiments. In both studies, all treatments significantly increased shoot dry weight compared with the untreated control. Oxathiapiprolin at both rates and fluopicolide at the high rate in both experiments and mandipropamid at the high rate in the second experiment had significantly $(P<0.05)$ higher shoot growth compared with the other treatments. Shoot dry weight of these treatments was increased between $192 \%$ (i.e., mandipropamid high rate, first experiment) and $265.5 \%$ (i.e., fluopicolide high rate, first experiment) compared with the untreated control. Root dry weight of inoculated plants was highest after using oxathiapiprolin at either rate or fluopicolide at the high rate in both experiments, mandipropamid at the high rate in the second experiment, or fluopicolide at the low rate in the first experiment. Increases compared with the control ranged from $192.8 \%$ (i.e., mandipropamid high rate, second experiment) to $306.5 \%$ (i.e., fluopicolide low rate, first experiment). Root dry weight was not significantly different compared with the control after potassium phosphite treatment in the first experiment.

Efficacy of Oomycota fungicides to control PRR of clonal avocado rootstocks. Only the higher of the two concentrations of fluopicolide, mandipropamid, and oxathiapiprolin from the seedling studies, and ethaboxam were evaluated in experiments with clonal rootstocks and compared with mefenoxam and potassium phosphite. Untreated plants of both rootstocks developed a similar incidence of PRR (i.e., $75.4 \%$ on Dusa and $80 \%$ on PS.54). All treatments significantly reduced the incidence of PRR compared with the untreated controls on both rootstocks (Fig. 4A, C). On Dusa, a significant difference among treatments was only observed between oxathiapiprolin with $2.1 \%$ incidence and potassium phosphite with $16.3 \%$ incidence. The other fungicides were all intermediate in efficacy. On PS.54, oxathiapiprolin resulted in the lowest incidence of PRR (i.e., $12.9 \%$ ), and this was statistically similar to fluopicolide ( $21.7 \%$ incidence). Ethaboxam at the rate used was the least effective of the fungicides with $51.7 \%$ incidence.

Pathogen propagules were effectively reduced by all treatments on the Dusa rootstock with no significant difference among treatments

Table 3. In vitro sensitivity ranges and mean values of effective concentrations to inhibit mycelial growth of 71 isolates of Phytophthora cinnamomi by $50 \%$ $\left(\mathrm{EC}_{50}\right.$ values) for the fungicides used in this study

\begin{tabular}{|c|c|c|c|c|c|c|c|c|c|c|}
\hline \multirow[b]{2}{*}{ Fungicide } & \multicolumn{3}{|c|}{ All isolates $(n=71)$} & \multicolumn{3}{|c|}{ Southern isolates $(n=46)^{\mathrm{w}}$} & \multicolumn{3}{|c|}{ Northern isolates $(n=25)^{x}$} & \multirow{2}{*}{$\begin{array}{c}\begin{array}{c}\text { Southern versus } \\
\text { northern means }\end{array} \\
P \text { value }\end{array}$} \\
\hline & Range & Mean & Tukey $^{\mathbf{z}}$ & Range & Mean & Tukey & Range & Mean & Tukey & \\
\hline Ethaboxam & $0.017-0.069$ & 0.035 & $\mathrm{~d}$ & $0.018-0.066$ & 0.034 & $\mathrm{dA}$ & $0.017-0.069$ & 0.037 & $\mathrm{dA}$ & 0.362 \\
\hline Fluopicolide & $0.046-0.330$ & 0.133 & $\mathrm{~b}$ & $0.046-0.330$ & 0.131 & b A & $0.069-0.257$ & 0.135 & b A & 0.637 \\
\hline Mandipropamid & $0.003-0.011$ & 0.005 & $\mathrm{e}$ & $0.003-0.011$ & 0.005 & e A & $0.003-0.011$ & 0.006 & e A & 0.217 \\
\hline Oxathiapiprolin & $0.0002-0.0007$ & 0.0004 & $\mathrm{f}$ & $0.0002-0.0006$ & 0.0003 & f A & $0.0002-0.0007$ & 0.0004 & f A & 0.053 \\
\hline Mefenoxam & $0.023-0.138$ & 0.061 & $\mathrm{c}$ & $0.026-0.138$ & 0.061 & c A & $0.023-0.100$ & 0.062 & c A & 0.866 \\
\hline Potassium phosphite & $12.9-361.2$ & 81.5 & $\mathrm{a}$ & $12.9-316.2$ & 98.9 & a A & $16.6-266.2$ & 47.3 & a B & 0.001 \\
\hline
\end{tabular}

${ }^{\mathrm{w}}$ Isolates collected in southern avocado growing areas of California (Riverside and San Diego counties).

x Isolates collected in northern avocado growing areas of California (Los Angeles, Santa Barbara, and Ventura counties).

${ }^{y}$ Mean $\mathrm{EC}_{50}$ values were analyzed using a general linear model for analysis of variance and the Tukey studentized range test for multiple mean comparisons with a $95 \%$ family-wise confidence level. Values followed by the same uppercase letter are not significantly different $(P>0.05)$ between southern and northern isolates for each fungicide in each row.

${ }^{\mathrm{z}}$ Mean $\mathrm{EC}_{50}$ values were analyzed using an analysis of variance and the Tukey studentized range test for multiple mean comparisons with a $95 \%$ family-wise confidence level. Values followed by the same lowercase letter are not significantly different $(P>0.05)$ from each other in each column. 
(Fig. 4B), still, mandipropamid, oxathiapiprolin, mefenoxam, and potassium phosphite reduced soil populations to zero levels. In contrast, on the PS.54 rootstock, only oxathiapiprolin significantly reduced P. cinnamomi populations in the soil (Fig. 4D).

Among the fungicides tested, all except mefenoxam significantly $(P \leq 0.05)$ increased root dry weight of inoculated PS.54 plants from that of control (Table 5). On Dusa rootstock, there was no significant difference in root dry weight among the six fungicides evaluated, but only ethaboxam-treated plants had a significantly higher root dry weight compared with the control.

\section{Discussion}

In this study, the four new Oomycota-targeting fungicides ethaboxam, fluopicolide, mandipropamid, and oxathiapiprolin demonstrated high in vitro toxicity with relatively low mean $\mathrm{EC}_{50}$ values to the avocado root rot pathogen $P$. cinnamomi. The in vitro

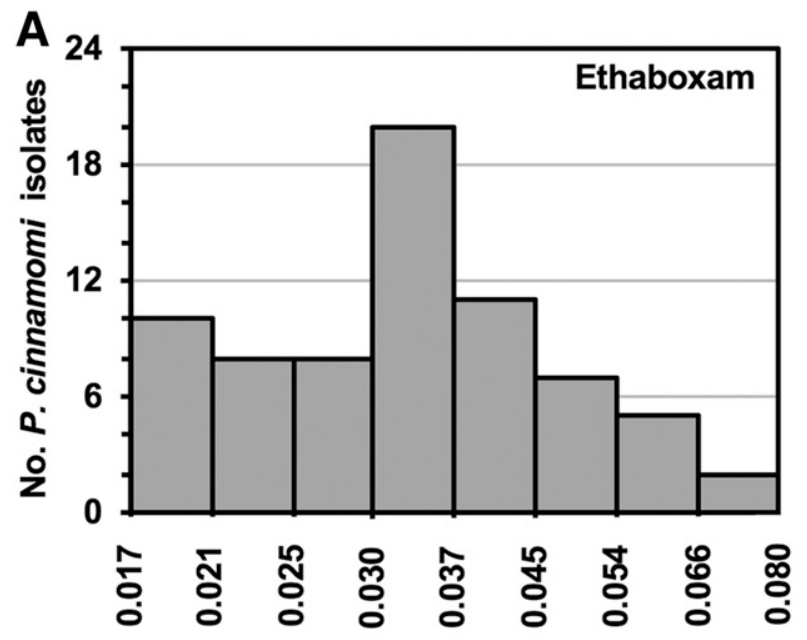

B
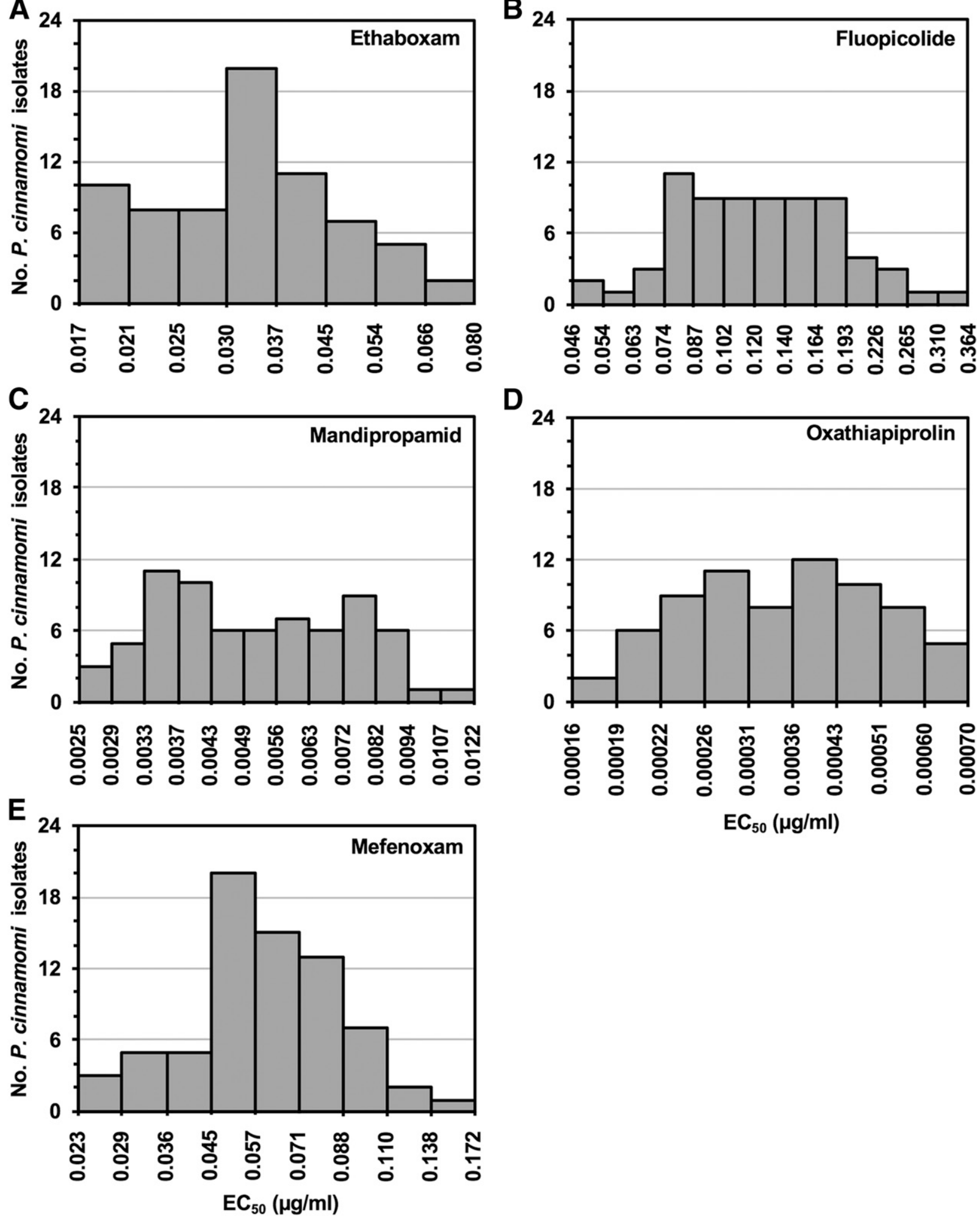

$D$

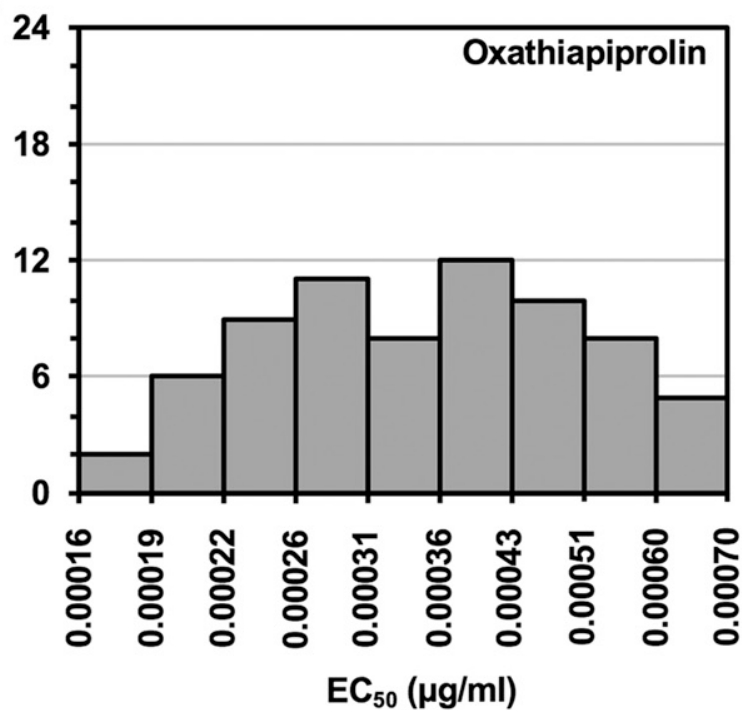

Fig. 1. Frequency histograms of effective concentrations to inhibit mycelial growth of 71 isolates of Phytophthora cinnamomi by $50 \%$ ( $E C_{50}$ values) for $A$, ethaboxam, $B$, fluopicolide, C, mandipropamid, D, oxathiapiprolin, and E, mefenoxam as determined by the spiral gradient dilution method. Bar height represents the number of isolates within each bin, and bin widths were calculated using the Scott (1979) method. 
sensitivities for each of these compounds displayed a unimodal distribution and a narrow range of $\mathrm{EC}_{50}$ values for mycelial growth inhibition of 71 isolates representing the current $P$. cinnamomi population in major avocado growing areas in California. The narrow ranges in sensitivities among isolates with no distinct less-sensitive outliers in the distribution may suggest a reduced potential for selection of resistance with the proper use of these fungicides. Because $P$. cinnamomi isolates were not previously exposed to ethaboxam, fluopicolide, mandipropamid, and oxathiapiprolin, the sensitivity ranges reported herein can be referred to as baseline distributions that can be used as references in future monitoring for fungicide resistance in populations of the pathogen.

In our study, oxathiapiprolin had the lowest $\mathrm{EC}_{50}$ values for all isolates among the new fungicides evaluated, ranging from 0.0002 to $0.0007 \mu \mathrm{g} / \mathrm{ml}$. This fungicide also was shown by others to be highly inhibitory to other Phytophthora spp. from a wide range of hosts, with mean $\mathrm{EC}_{50}$ values of $<0.001 \mu \mathrm{g} / \mathrm{ml}$ (Belisle et al. 2019; Ji and Csinos 2015; Martin et al. 2014; Miao et al. 2016b; Qu et al. 2016). Similarly, Gray et al. (2018) found that oxathiapiprolin had the lowest range of $\mathrm{EC}_{50}$ values of 0.0002 to $0.0015,0.0002$ to $0.0003,0.0003$ to 0.001 , and $<0.0003 \mu \mathrm{g} / \mathrm{ml}$ for $P$. citrophthora, $P$. syringae, $P$. nicotianae, and $P$. hibernalis, respectively, compared with the other three compounds. Together, reported inhibitory values for oxathiapiprolin are generally 10- to 1,000-fold lower than those for ethaboxam, fluopicolide, mandipropamid, and mefenoxam, depending on the fungicide-species combination. Thus, the in vitro toxicity of oxathiapiprolin to $P$. cinnamomi from avocado reported in our study is lower than for any previous fungicide evaluated against this pathogen.

$\mathrm{EC}_{50}$ values for fluopicolide, mandipropamid, and ethaboxam for $P$. cinnamomi in our study were also within the range of values previously determined for several other Phytophthora spp. (Belisle et al. 2019; Gray et al. 2018; Jackson et al. 2010; Jiang et al. 2015; Kim et al. 2004; Qu et al. 2016; Saville et al. 2015). The range of $\mathrm{EC}_{50}$ values for mefenoxam in our study ( 0.023 to $0.138 \mu \mathrm{g} / \mathrm{ml})$ was similar to that previously reported for $P$. cinnamomi from avocado (Belisle et al. 2019), Fraser fir (Benson and Grand 2000), and woody ornamentals (Duan et al. 2008; Hu et al. 2010) in the United States. Thus, the current usage pattern for this fungicide to control avocado PRR in California nurseries and orchards has not resulted in mefenoxam resistance in $P$. cinnamomi populations.
In contrast to the other fungicides, a wide range of in vitro sensitivities was detected for potassium phosphite, and there was a significant difference in mean $\mathrm{EC}_{50}$ values between isolates from the two geographical regions, confirming a previous report (Belisle et al. 2019). The higher value for isolates from southern California production areas may be attributable to higher field rates or more frequent applications of potassium phosphite to manage PRR in avocado orchards. The bimodal distribution for the 71 isolates in this study separates the current pathogen population into two sensitivity groups indicating a shift in population sensitivity. A baseline for this compound, however, was not established before commercial field usage. However, prolonged use of phosphite caused a shift toward reduced sensitivity of $P$. cinnamomi isolates from avocado orchards in Australia (Dobrowolski et al. 2008) and South Africa (Ma and McLeod 2014). Phosphonate (e.g., fosetyl-Al) resistance has also been reported for P. cinnamomi from Chamaecyparis lawsoniana in nurseries (Vegh et al. 1985), for downy mildew of lettuce (Brown et al. 2004), and in P. citrophthora, P. nicotianae, and P. syringae from citrus in California (Adaskaveg et al. 2017). With direct and indirect effects on the pathogen, the resistance potential of potassium phosphite is considered relatively low (Dobrowolski et al. 2008). The extensive and often sole use of this FRAC group in California avocado orchards to combat PRR (Coffey et al. 1984; Darvas and Becker 1984), however, is expected to eventually lead to resistance.

In our greenhouse studies, avocado seedlings and rootstocks were inoculated with $P$. cinnamomi isolates from southern avocado production areas that have been described as more virulent (Belisle et al. 2019). A high incidence of PRR developed on untreated control plants of seedlings and both rootstocks with more than $75 \%$ of plated root pieces colonized by the pathogen. The high incidence on the Dusa rootstock that is considered more tolerant to PRR is likely attributable to our selection of discolored root pieces for plating of all samples. The four new fungicides were moderately to highly effective in reducing PRR and $P$. cinnamomi populations in rhizosphere soil of the avocado seedlings and rootstocks used. Overall, oxathiapiprolin was the most effective among fungicides evaluated. In experiments with Zutano seedlings, the efficacy of oxathiapiprolin at the low rate of $70 \mathrm{~g} / \mathrm{ha}$ was two to 33 times higher than that of the other fungicides and two to four times higher than that of mandipropamid, a CAA fungicide. In a study on managing $P$. capsici on peppers (Miao et al. 2016b), the difference in effectiveness of

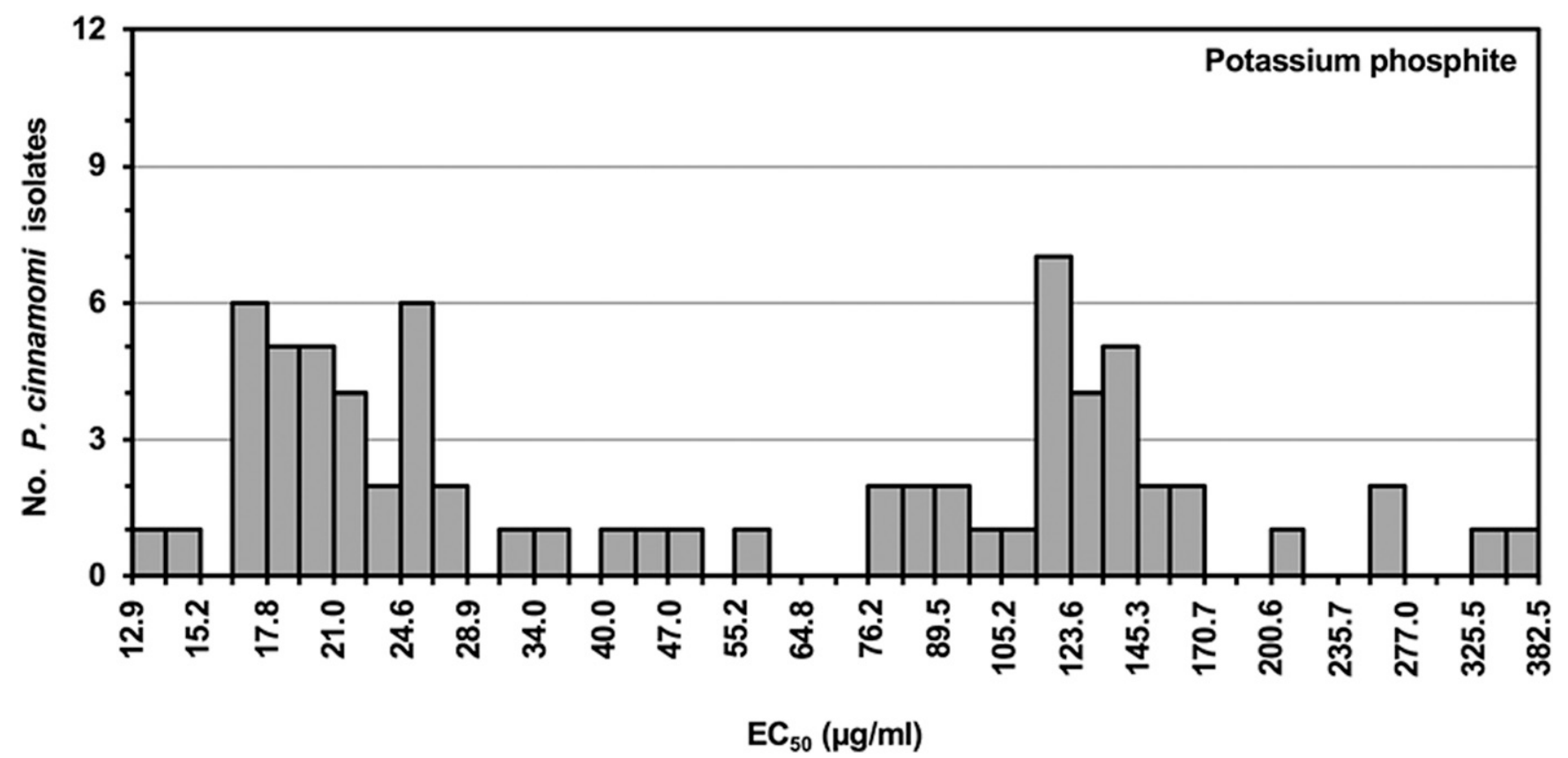

Fig. 2. Frequency histogram of effective concentrations to inhibit mycelial growth of 71 isolates of Phytophthora cinnamomi by $50 \%$ (EC 50 values) for potassium phosphite as determined by the agar dilution method. Bar height represents the number of isolates within each bin, and bin widths (i.e., $10^{0.03503} \mu \mathrm{g} / \mathrm{ml}$ ) were calculated using the Scott (1979) method. 
oxathiapiprolin at $30 \mathrm{~g} / \mathrm{ha}$ compared with the CAA dimethomorph at $262.5 \mathrm{~g} / \mathrm{ha}$ was similar to our study using the same FRAC codes of fungicides. In response to reducing PRR, avocado plants treated with oxathiapiprolin generally developed more shoot and root growth compared with untreated plants.

On the avocado seedlings and rootstocks used, fluopicolide, mandipropamid, and ethaboxam treatments also effectively reduced the incidence of PRR compared with the control. P. cinnamomi propagules in the rhizosphere soil were only significantly reduced on the Zutano seedlings and the Dusa rootstock. These latter treatments were often significantly more effective than potassium phosphite or mefenoxam, whereas fluopicolide often performed statistically similar to oxathiapiprolin. However, the efficacy of potassium phosphite was demonstrated with significant reductions in PRR on the seedlings and rootstocks although its overall performance may have been compromised by the use of three $P$. cinnamomi isolates with reduced sensitivities to the fungicide (i.e., $\mathrm{EC}_{50}$ values between 116.7 and $165.3 \mu \mathrm{g} / \mathrm{ml}$ ) in our soil inoculations. These results also could explain why potassium phosphite is still effectively used in managing PRR in California since many growers cultivate avocado trees grafted on the Dusa rootstock.
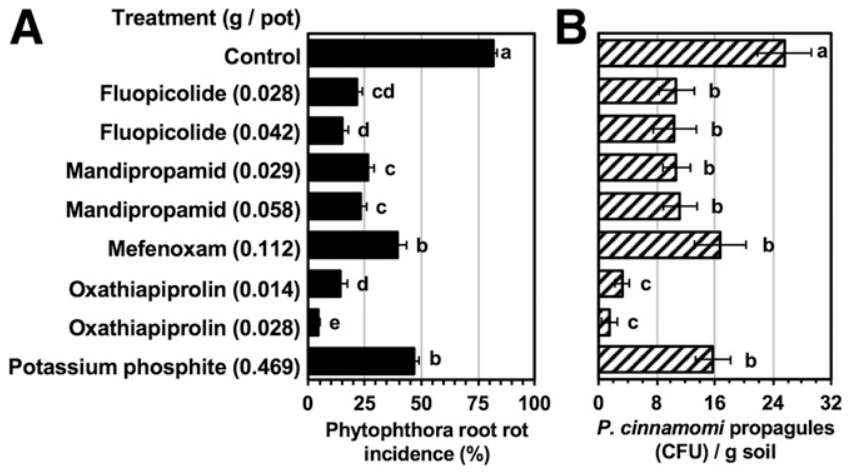

Fig. 3. Efficacy of new Oomycota fungicides to manage $\mathbf{A}$, Phytophthora root rot of Zutano avocado seedlings and B, rhizosphere populations of Phytophthora cinnamomi under greenhouse conditions. Bars followed by the same letter are not significantly different according to the Fisher least significance difference test at $P>$ 0.05 . Standard error bars are also shown.

Table 4. Effect of new Oomycota fungicides on shoot and root dry weights of Zutano avocado seedlings inoculated with Phytophthora cinnamomi in greenhouse studies

\begin{tabular}{|c|c|c|c|c|}
\hline \multirow[b]{2}{*}{ Treatment (g/pot) } & \multicolumn{2}{|c|}{ First experiment } & \multicolumn{2}{|c|}{ Second experiment } \\
\hline & $\begin{array}{l}\text { Shoot DWy } \\
\text { (g) }\end{array}$ & $\begin{array}{l}\text { Root DW } \\
\text { (g) }\end{array}$ & $\begin{array}{c}\text { Shoot DW } \\
\text { (g) }\end{array}$ & $\begin{array}{c}\text { Root DW } \\
\text { (g) }\end{array}$ \\
\hline Control & $31.9 \mathrm{c}^{\mathrm{z}}$ & $9.3 \mathrm{e}$ & $46.0 \mathrm{e}$ & $16.6 \mathrm{f}$ \\
\hline Fluopicolide (0.028) & $79.1 \mathrm{a}$ & $28.5 \mathrm{a}$ & $80.6 \mathrm{bc}$ & 30.4 bcde \\
\hline Fluopicolide (0.042) & $84.7 \mathrm{a}$ & $25.7 \mathrm{ab}$ & $94.9 \mathrm{a}$ & $34.9 \mathrm{ab}$ \\
\hline $\begin{array}{l}\text { Mandipropamid } \\
(0.029)\end{array}$ & $56.5 \mathrm{~b}$ & $20.2 \mathrm{bcd}$ & $77.4 \mathrm{bc}$ & $29.3 \mathrm{abc}$ \\
\hline $\begin{array}{l}\text { Mandipropamid } \\
(0.058)\end{array}$ & $58.9 \mathrm{~b}$ & $17.6 \mathrm{~cd}$ & $88.6 \mathrm{ab}$ & $32.0 \mathrm{abcd}$ \\
\hline Mefenoxam (0.112) & $48.6 \mathrm{~b}$ & $17.6 \mathrm{~cd}$ & $73.8 \mathrm{~cd}$ & $25.3 \mathrm{e}$ \\
\hline $\begin{array}{l}\text { Oxathiapiprolin } \\
(0.014)\end{array}$ & $76.4 \mathrm{a}$ & $24.4 \mathrm{abc}$ & $96.8 \mathrm{a}$ & $33.3 \mathrm{abc}$ \\
\hline $\begin{array}{l}\text { Oxathiapiprolin } \\
(0.028)\end{array}$ & $81.5 \mathrm{a}$ & $24.4 \mathrm{abc}$ & $94.4 \mathrm{a}$ & $36.4 \mathrm{a}$ \\
\hline $\begin{array}{l}\text { Potassium phosphite } \\
(0.469)\end{array}$ & $53.1 \mathrm{~b}$ & $15.7 \mathrm{de}$ & $62.8 \mathrm{~d}$ & $26.6 \mathrm{de}$ \\
\hline
\end{tabular}

${ }^{y}$ Dry weight (DW) of shoots and roots of each plant was measured after drying at $50^{\circ} \mathrm{C}$ for 5 days.

${ }^{\mathrm{z}}$ Numbers followed by the same letter are not significantly different according to the Fisher least significance difference test at $P>0.05$.
Thus, highly effective alternatives to mefenoxam and the phosphonates were identified by us for the management of avocado PRR. Oxathiapiprolin used at low rates provided similar or better efficacy than the other fungicides. Oxathiapiprolin, fluopicolide, mandipropamid, and ethaboxam previously demonstrated high efficacy against selected foliar and root diseases of vegetable and tree crops caused by Oomycota organisms in greenhouse and field studies. For example, the four fungicides were highly efficacious in reducing PRR of citrus caused by $P$. nicotianae and $P$. citrophthora (Hao et al. 2019). Oxathiapiprolin, fluopicolide, and mandipropamid were more effective in managing $P$. capsici on watermelon than mefenoxam or potassium phosphite (Kousik et al. 2011, 2016). In other studies, oxathiapiprolin was shown to be highly effective in managing diseases of vegetable crops caused by Phytophthora species including $P$. capsici (Ji and Csinos 2015; Miao et al. 2016b) and P. infestans (Pasteris et al. 2016) and controlled black shank of tobacco caused by $P$. nicotianae (Bittner and Mila 2016; Ji et al. 2014). Ethaboxam was shown to be an effective treatment for tomato late blight $(P$. infestans), as well as Phytophthora blight (P. capsici) of pepper (Kim et al. 2004).
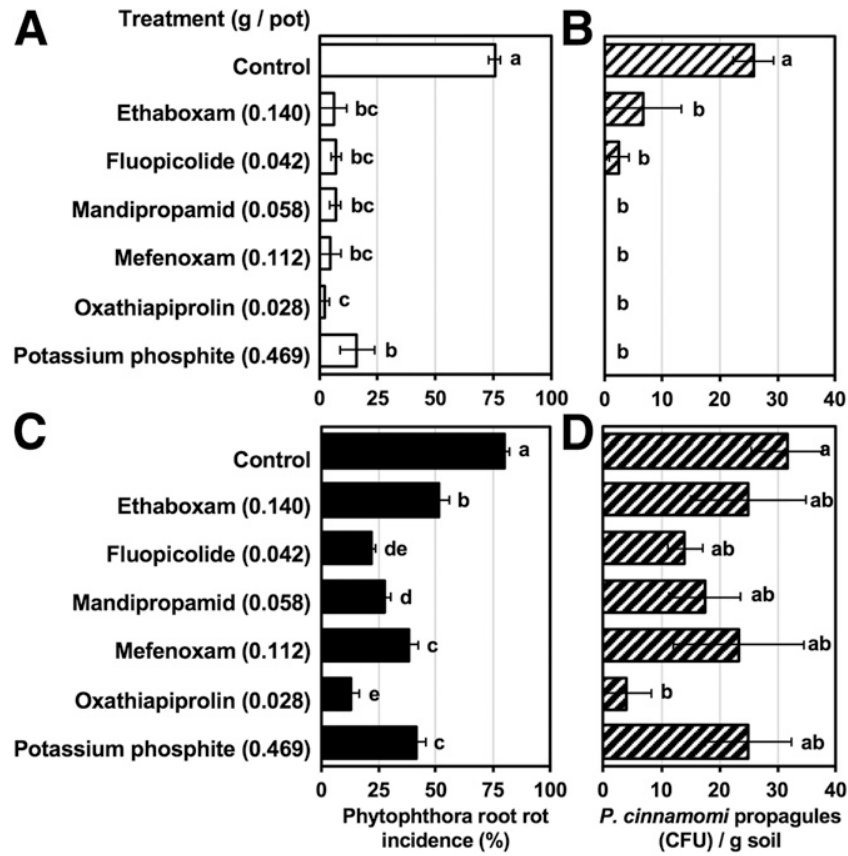

Fig. 4. Efficacy of new Oomycota fungicides to manage $A$ and $C$, Phytophthora root rot and $\mathbf{B}$ and $\mathbf{D}$, rhizosphere populations of Phytophthora cinnamomi of clonal avocado rootstocks A and B, Dusa and C and D, PS.54 under greenhouse conditions. Bars followed by the same letter are not significantly different according to the Fisher least significance difference test at $P>0.05$. Standard error bars are also shown.

Table 5. Effect of new Oomycota fungicides on root dry weights of Dusa and PS.54 avocado rootstocks inoculated with Phytophthora cinnamomi in greenhouse studies

\begin{tabular}{llc}
\hline & \multicolumn{2}{c}{ Root DW $^{\mathbf{y}}(\mathbf{g})$} \\
\cline { 2 - 3 } Treatment (g/pot) & Dusa & PS.54 \\
\hline Control & $20.1 \mathrm{~b}^{\mathbf{z}}$ & $16.2 \mathrm{c}$ \\
Ethaboxam (0.140) & $25.4 \mathrm{a}$ & $28.6 \mathrm{ab}$ \\
Fluopicolide (0.042) & $22.2 \mathrm{ab}$ & $28.1 \mathrm{ab}$ \\
Mandipropamid (0.058) & $20.4 \mathrm{~b}$ & $28.5 \mathrm{ab}$ \\
Mefenoxam (0.11) & $22.6 \mathrm{ab}$ & $22.6 \mathrm{bc}$ \\
Oxathiapiprolin $(0.028)$ & $23.5 \mathrm{ab}$ & $31.4 \mathrm{a}$ \\
Potassium phosphite $(0.469)$ & $22.3 \mathrm{ab}$ & $30.2 \mathrm{ab}$ \\
\hline
\end{tabular}

${ }^{\mathrm{y}}$ Root dry weight (DW) of each plant was measured after drying the samples at $50^{\circ} \mathrm{C}$ for 5 days.

${ }^{\mathrm{z}}$ Numbers followed by the same letter are not significantly different according to Fisher's least significance difference test at $P>0.05$. 
Based on our studies, registration of oxathiapiprolin for use on avocado has been initiated through the Interregional Research Project No. 4, and ethaboxam, fluopicolide, and mandipropamid are proposed for further development on avocado. Additional evaluations will have to be done under field conditions using rootstocks with different growth characteristics and susceptibilities to PRR. To our knowledge, the registrant plans to label oxathiapiprolin and mandipropamid for use as a soil application or chemigation in avocado orchards. We expect fluopicolide and ethaboxam to be registered and labeled as a soil application, similar to the fluopicolide registration on citrus. Oxathiapiprolin is considered to have a medium to high risk for resistance development; mandipropamid and ethaboxam are considered to have a low to medium risk, whereas the risk is unknown for fluopicolide (Fungicide Resistance Action Committee 2018). Oxathiapiprolin-resistant $P$. capsici isolates have been obtained by ultraviolet mutagenesis, and the mutation occurred at the OSBP gene (Pasteris et al. 2016). However, no resistance has been found in surveys of natural populations of $P$. capsici (Miao et al. 2016a). In contrast, mandipropamid resistance has been reported in field populations of Plasmopara viticola (Blum et al. 2010; Sierotzki et al. 2011), Pseudoperonospora cubensis (Blum et al. 2011), and Pythium aphanidermatum (Blum and Gisi 2012). Because of the high efficacy and the potential for resistance against these singlesite mode of action fungicides, the registrants most likely will limit the number of applications to once per year on avocado.

The availability of fungicides with new modes of action and options for rotation and mixture programs using previously registered and new fungicides will help reduce the risk of development and spread of resistance in P. cinnamomi populations in California avocado production. Growers currently rely heavily on the use of phosphonate-based fungicides, and as we demonstrated, pathogen populations are shifting toward reduced sensitivity to this fungicide class. Thus, there is an urgent need to register fungicides with new modes of action. In our greenhouse studies, overall treatment efficacy in reducing PRR and soil inoculum levels of the pathogen on the susceptible PS.54 was reduced compared with the more tolerant Dusa rootstock, indicating additive effects of fungicide use and rootstock selection. In an integrated approach for a durable and effective management of PRR that allows the continued economical production of avocados in P. cinnamomi-infested soils, the use of tolerant rootstocks is critical along with irrigation management and cultural practices such as using mulching and planting in areas with good soil drainage.

\section{Acknowledgments}

We thank G. Ntwali, D. Murillo, and G. Gemelga for assisting in greenhouse experiments. We also thank Dr. A. Eskalen for providing 14 P. cinnamomi isolates, the agrochemical industries for supplying fungicides for evaluation, and Dr. H. Förster and Dr. William E. Fry for critically reviewing this manuscript.

\section{Literature Cited}

Adaskaveg, J. E., Förster, H., Hao, W., and Gray, M. 2017. Potassium phosphite resistance and new modes of action for managing Phytophthora diseases of citrus in the United States. Pages 205-210 in: Modern Fungicides and Antifungal Compounds. H. B. Deising, B. Fraaije, A. Mehl, E. C. Oerke, H. Sierotzki, and G. Stammler, eds. Vol. VIII. Deutsche Phytomedizinische Gesellschaft, Braunschweig, Germany.

Adaskaveg, J. E., Hao, W., and Förster, H. 2015. Postharvest strategies for managing Phytophthora brown rot of citrus using potassium phosphite in combination with heat treatments. Plant Dis. 99:1477-1482.

Belisle, R. J., McKee, B., Hao, W., Crowley, M., Arpaia, M. L., Miles, T. D., Adaskaveg, J. E., and Manosalva, P. 2019. Phenotypic characterization of genetically distinct Phytophthora cinnamomi isolates from avocado. Phytopathology 109:384-394.

Bender, G., Menge, J., and Arpaia, M. L. 2013. Avocado rootstocks. Pages 45-53 in: Avocado Production in California: A Cultural Handbook for Growers. Book 1: Background Information, 2nd ed. G. S. Bender, ed. University of California Cooperative Extension, San Diego County and California Avocado Society.

Benson, D. M., and Grand, L. F. 2000. Incidence of Phytophthora root rot of Fraser fir in North Carolina and sensitivity of isolates of Phytophthora cinnamomi to metalaxyl. Plant Dis. 84:661-664.

Bilodeau, G. J., Martin, F. N., Coffey, M. D., and Blomquist, C. L. 2014. Development of a multiplex assay for genus- and species-specific detection of Phytophthora based on differences in mitochondrial gene order. Phytopathology 104:733-748.

Bittner, R. J., and Mila, A. L. 2016. Effects of oxathiapiprolin on Phytophthora nicotianae, the causal agent of black shank of tobacco. Crop Prot. 81:57-64.

Blum, M., and Gisi, U. 2012. Insights into the molecular mechanism of tolerance to carboxylic acid amide (CAA) fungicides in Pythium aphanidermatum. Pest Manag. Sci. 68:1171-1183.

Blum, M., Waldner, M., and Gisi, U. 2010. A single point mutation in the novel $P v C e s A 3$ gene confers resistance to the carboxylic acid amide fungicide mandipropamid in Plasmopara viticola. Fungal Genet. Biol. 47:499-510.

Blum, M., Waldner, M., Olaya, G., Cohen, Y., Gisi, U., and Sierotzki, H. 2011. Resistance mechanism to carboxylic acid amide fungicides in the cucurbit downy mildew pathogen Pseudoperonospora cubensis. Pest Manag. Sci. 67: 1211-1214.

Briggs, G., Mansfield, D., Moloney, B., Gary, S., and Wegmann, T. 2006. The discovery and chemistry of fluopicolide: A new standard for oomycetes disease control. Pflanzenschutz Nachr. Bayer 59:141-152.

Brown, S., Koike, S. T., Ochoa, O. E., Laemmlen, F., and Michelmore, R. W. 2004. Insensitivity to the fungicide fosetyl-aluminum in California isolates of the lettuce downy mildew pathogen, Bremia lactucae. Plant Dis. 88:502-508.

Coffey, M. D. 1987. Phytophthora root rot of avocado - an integrated approach to control in California. Calif. Avocado Soc. Yearb. 71:121-137.

Coffey, M. D., Klure, L. J., and Bower, L. A. 1984. Variability in sensitivity to metalaxyl of isolates of Phytophthora cinnamomi and Phytophthora citricola. Phytopathology 74:417-422.

Cohen, Y., and Samoucha, Y. 1984. Cross-resistance to four systemic fungicides in metalaxyl-resistant strains of Phytophthora infestans and Pseudoperonospora cubensis. Plant Dis. 68:137-139.

Cooke, D. E., Drenth, A., Duncan, J. M., Wagels, G., and Brasier, C. M. 2000. A molecular phylogeny of Phytophthora and related oomycetes. Fungal Genet. Biol. 30:17-32.

Cooke, D. E., and Duncan, J. M. 1997. Phylogenetic analysis of Phytophthora species based on ITS1 and ITS2 sequences of the ribosomal RNA gene repeat. Mycol. Res. 101:667-677.

Darvas, J. M., and Becker, O. 1984. Failure to control Phytophthora cinnamomi and Pythium splendens with metalaxyl after its prolonged use. South African Avocado Growers Assoc. Yearb. 7:77-78.

Dobrowolski, M. P., Shearer, B. L., Colquhoun, I. J., O'Brien, P. A., and Hardy, G. E. 2008. Selection for decreased sensitivity to phosphite in Phytophthora cinnamomi with prolonged use of fungicide. Plant Pathol. 57:928-936.

Drenth, A., and Sendall, B. 2001. Inoculation of soil. Pages 37-38 in: Practical Guide to Detection and Identification of Phytophthora. Cooperative Research Centre for Tropical Plant Protection, Brisbane, Australia.

Duan, C. H., Riley, M. B., and Jeffers, S. N. 2008. Characterization of Phytophthora cinnamomi populations from ornamental plants in South Carolina, USA. Arch. Phytopathol. Plant Prot. 41:14-30.

Erwin, D. C., and Ribeiro, O. K. 1996. Phytophthora Diseases Worldwide. American Phytopathological Society, St. Paul, MN.

Eshraghi, L., Anderson, J. P., Aryamanesh, N., Mccomb, J. A., Shearer, B. L., and Hardy, G. E. St. J. 2014. Defence signalling pathways involved in plant resistance and phosphite-mediated control of Phytophthora cinnamomi. Plant Mol. Biol. Report 32:342-356.

Eskalen, A., and Faber, B. A. 2016. Phytophthora fruit rot. Pages 86-90 in: UC IPM Pest Management Guidelines Avocado. B. A. Faber, C. A. Willen, A. Eskalen, J. G. Morse, B. Hanson, and M. S. Hoddle, eds. University of California Agriculture and Natural Resources Publication 3436. University of California, Oakland.

Fenn, M. E., and Coffey, M. D. 1984. Studies on the in vitro and in vivo antifungal activity of fosetyl-A1 and phosphorous acid. Phytopathology 74:606-611.

Ferguson, A. J., and Jeffers, S. N. 1999. Detecting multiple species of Phytophthora in container mixes from ornamental crop nurseries. Plant Dis. 83:1129-1136.

Ferrin, D. M., and Kabashima, J. N. 1991. In vitro insensitivity to metalaxyl of isolates of Phytophthora citricola and P. parasitica from ornamental hosts in southern California. Plant Dis. 75:1041-1044.

Förster, H., Kanetis, L., and Adaskaveg, J. E. 2004. Spiral gradient dilution, a rapid method for determining growth responses and $50 \%$ effective concentration values in fungus-fungicide interactions. Phytopathology 94:163-170.

Fungicide Resistance Action Committee. 2018. FRAC Code List: Fungicides Sorted by Mode of Action. Online publication. http://www.frac.info.

Gisi, U., and Sierotzki, H. 2015. Oomycete fungicides: Phenylamides, quinone outside inhibitors, and carboxylic acid amides. Pages 145-174 in: Fungicide Resistance in Plant Pathogens. Ishii, H., and Hollomon, D. W., eds. Springer, Tokyo, Japan.

Gray, M., Hao, W., Forster, H., and Adaskaveg, J. 2018. Baseline sensitivities of new fungicides and their toxicity to selected life stages of Phytophthora species from citrus in California. Plant Dis. 102:734-742.

Groves, E., Howard, K., Hardy, G., and Burgess, T. 2015. Role of salicylic acid in phosphite-induced protection against Oomycetes; a Phytophthora cinnamomiLupinus augustifolius model system. Eur. J. Plant Pathol. 141:559-569.

Hall, T. A. 1999. BioEdit: A user-friendly biological sequence alignment editor and analysis program for Windows 95/98/NT. Nucl. Acids. Symp. Ser. 41 95-98. 
Hao, W., Gray, M. A., Förster, H., and Adaskaveg, J. E. 2019. Evaluation of new Oomycota fungicides for management of Phytophthora root rot of citrus in California. Plant Dis. 103:619-628.

Hao, W., Miles, T. D., Martin, F. N., Browne, G., Förster, H., and Adaskaveg, J. E. 2018. Temporal occurrence and niche preferences of Phytophthora species causing brown rot of citrus in the Central Valley of California. Phytopathology 108:384-391.

Hardham, A. R. 2005. Phytophthora cinnamomi. Mol. Plant Pathol. 6:589-604.

Hu, J., Hong, C., Stromberg, E. L., and Moorman, G. W. 2010. Mefenoxam sensitivity in Phytophthora cinnamomi isolates. Plant Dis. 94:39-44.

Hwang, J., and Benson, D. M. 2005. Identification, mefenoxam sensitivity, and compatibility type of Phytophthora spp. attacking floriculture crops in North Carolina. Plant Dis. 89:185-190.

Jackson, K. L., Yin, J., Csinos, A. S., and Ji, P. 2010. Fungicidal activity of fluopicolide for suppression of Phytophthora capsici on squash. Crop Prot. 29:1421-1427.

Ji, P., and Csinos, A. S. 2015. Effect of oxathiapiprolin on asexual life stages of Phytophthora capsici and disease development on vegetables. Ann. Appl. Biol. 166:229-235.

Ji, P., Csinos, A. S., Hickman, L. L., and Hargett, U. 2014. Efficacy and application methods of oxathiapiprolin for management of black shank on tobacco. Plant Dis. 98:1551-1554.

Jiang, L., Wang, H., Xu, H., Qiao, K., Xia, X., and Wang, K. 2015. Transportation behaviour of fluopicolide and its control effect against Phytophthora capsici in greenhouse tomatoes after soil application. Pest Manag. Sci. 71:1008-1014.

Kamoun, S., Furzer, O., Jones, J. D. G., Judelson, H. S., Ali, G. S., Dalio, R. J., Roy, S. G., Schena, L., Zambounis, A., Panabières, F., Cahill, D., Ruocco, M., Figueiredo, A., Chen, X. R., Hulvey, J., Stam, R., Lamour, K., Gijzen, M., Tyler, B. M., Grünwald, N. J., Mukhtar, M. S., Tomé, D. F., Tör, M., Van Den Ackerveken, G., McDowell, J., Daayf, F., Fry, W. E., LindqvistKreuze, H., Meijer, H. J., Petre, B., Ristaino, J., Yoshida, K., Birch, P. R., and Govers, F. 2015. The top 10 oomycete pathogens in molecular plant pathology. Mol. Plant Pathol. 16:413-434.

Kim, D.-S., Chun, S.-J., Jeon, J.-J., Lee, S.-W., and Joe, G.-H. 2004. Synthesis and fungicidal activity of ethaboxam against Oomycetes. Pest Manag. Sci. 60: 1007-1012.

King, M., Reeve, W., Van der Hoek, M. B., Williams, N., McComb, J., O’Brien, P. A., and Hardy, G. E. St. J. 2010. Defining the phosphite-regulated transcriptome of the plant pathogen Phytophthora cinnamomi. Mol. Genet. Genomics 284: $425-435$.

Kousik, C., Egel, D., Ji, P., and Quesada-Ocampo, L. 2016. Fungicide rotation schemes and Melcast for managing Phytophthora fruit rot of watermelon in Southeastern United States. (Abstr.) Phytopathology 106:S4.68-69.

Kousik, C. S., Adams, M. L., Jester, W. R., Hassell, R., Harrison, H. F., and Holmes, G. J. 2011. Effect of cultural practices and fungicides on Phytophthora fruit rot of watermelon in the Carolinas. Crop Prot. 30:888-894.

Ma, J., and McLeod, A. 2014. In vitro sensitivity of South African Phytophthora cinnamomi to phosphite at different phosphate concentrations. South African Avocado Growers Assoc. Yearb. 37:79-84.

Martin, F. N., Blair, J. E., and Coffey, M. D. 2014. A combined mitochondrial and nuclear multilocus phylogeny of the genus Phytophthora. Fungal Genet. Biol. 66:19-32.

Matkin, O. A., and Chandler, P. A. 1957. The U.C. type soil mixes. Pages 68-85 in: The U.C. System for Producing Healthy Container-Grown Plants. University of California Agriculture and Natural Resources Manual 23. K. F. Baker, ed. University of California, Berkeley.

McCarren, K., McComb, J. A., Shearer, B., and Hardy, G. 2005. The role of chlamydospores of Phytophthora cinnamomi - A review. Australas. Plant Pathol. 34:333-338.

Miao, J., Cai, M., Dong, X., Liu, L., Lin, D., Zhang, C., Pang, Z., and Liu, X. 2016a. Resistance assessment for oxathiapiprolin in Phytophthora capsici and the detection of a point mutation $(\mathrm{G} 769 \mathrm{~W})$ in PcORP1 that confers resistance. Front. Microbiol. 7:615.
Miao, J., Dong, X., Lin, D., Wang, Q., Liu, P., Chen, F., Du, Y., and Liu, X. 2016b. Activity of the novel fungicide oxathiapiprolin against plant-pathogenic oomycetes. Pest Manag. Sci. 72:1572-1577.

Miles, T. D., Martin, F. N., Robideau, G. P., Bilodeau, G. J., and Coffey, M. D. 2017. Systematic development of Phytophthora species-specific mitochondrial diagnostic markers for economically important members of the genus. Plant Dis. 101:1162-1170.

Mircetich, S. M., Browne, G. T., Krueger, W., and Schreader, W. 1985. Phytophthora spp. isolated from surface water irrigation sources in California. (Abstr.) Phytopathology 75:1346

Müller, U., and Gisi, U. 2012. Newest aspects of nucleic acid synthesis inhibitors: Metalaxyl-M. Pages 901-908 in: Modern Crop Protection Compounds, 2nd ed. W. Krämer, U. Schirmer, P. Jeschke, and M. Witschel eds. Wiley, Weinheim, Germany.

Ouimette, D. G., and Coffey, M. D. 1989. Comparative antifungal activity of four phosphonate compounds against isolates of nine Phytophthora species. Phytopathology 79:761-767.

Pagliaccia, D., Pond, E., McKee, B., and Douhan, G. W. 2013. Population genetic structure of Phytophthora cinnamomi associated with avocado in California and the discovery of a potentially recent introduction of a new clonal lineage. Phytopathology 103:91-97.

Pasteris, R. J., Hanagan, M. A., Bisaha, J. J., Finkelstein, B. L., Hoffman, L. E., Gregory, V., Andreassi, J. L., Sweigard, J. A., Klyashchitsky, B. A., Henry, Y. T., and Berger, R. A. 2016. Discovery of oxathiapiprolin, a new oomycete fungicide that targets an oxysterol binding protein. Bioorg. Med. Chem. 24:354-361.

Qu, T., Shao, Y., Csinos, A. S., and Ji, P. 2016. Sensitivity of Phytophthora nicotianae from tobacco to fluopicolide, mandipropamid, and oxathiapiprolin. Plant Dis. 100:2119-2125.

Ribeiro, O. K. 1978. A Source Book of the Genus Phytophthora. J. Cramer, Vaduz, Liechtenstein.

Saville, A., Graham, K., Grünwald, N. J., Myers, K., Fry, W. E., and Ristaino, J. B. 2015. Fungicide sensitivity of U.S. genotypes of Phytophthora infestans to six oomycete-targeted compounds. Plant Dis. 99:659-666.

Scott, D. W. 1979. On optimal and data-based histograms. Biometrika 66:605-610.

Sierotzki, H., Blum, M., Olaya, G., Waldner-Zulauf, M., Buitrago, C. Wullschleger, J., Cohen, Y., and Gisi, U. 2011. Sensitivity to CAA fungicides and frequency of mutations in cellulose synthase (CesA3) gene of oomycete pathogen populations. Pages 103-110 in: Modern Fungicides and Antifungal Compounds VI. H. W. Dehne, H. B. Deising, U. Gisi, K. H. Kuck, P. E. Russell, and H. Lyr, eds. Proceedings of the 16th International Reinhardsbrunn Symposium. DPG Selbstverlag, Braunschweig, Germany.

Stack, J., and Millar, R. 1985. Isolation and characterization of a metalaxylinsensitive isolate of Phytophthora megasperma f. sp. medicaginis. Phytopathology 75:1387-1392.

Uchida, M., Roberson, R. W., Chun, S.-J., and Kim, D.-S. 2005. In vivo effects of the fungicide ethaboxam on microtubule integrity in Phytophthora infestans. Pest Manag. Sci. 61:787-792.

Veena, S. S., Anandaraj, M., and Sarma, Y. R. 2010. Variability in the sensitivity of Phytophthora capsici isolates to potassium phosphonate. Indian Phytopathol. 63:71-75

Vegh, I., Leroux, P., LeBerre, A., and Lanen, C. 1985. Detection sur Chamaecyparis lawsoniana 'Elwoodii' d'une souche de Phytophthora cinnamomi Rands resistante au phosethyl-Al. Revue. Horticole. 262:19-21.

White, T. J., Bruns, T., Lee, S., and Taylor, J. 1990. Amplification and direct sequencing of fungal ribosomal RNA genes for phylogenetics. Pages 315-322 in: PCR Protocols: A Guide to Methods and Applications. M. A. Innis, J. J. Gelfand, J. J. Sninsky, and T. J. White, eds. Academic Press, San Diego, CA.

Wilkinson, C. J., Shearer, B. L., Jackson, T. J., and Hardy, G. E. S. 2001. Variation in sensitivity of Western Australian isolates of Phytophthora cinnamomi to phosphite in vitro. Plant Pathol. 50:83-89.

Zentmyer, G. A. 1961. Chemotaxis of zoospores for root exudates. Science 133: 1595-1596.

Zentmyer, G. A. 1980. Phytophthora cinnamomi and the Diseases It Causes. Monograph No. 10. American Phytopathological Society, St. Paul, MN. 